\title{
MEMBACA PEMIKIRAN BEDIUZZAMAN SAID NURSI TENTANG SIGNIFIKANSI AGAMA DAN IDENTITAS BAGI KEMAJUAN SOSIAL
}

\author{
Ustadi Hamsah \\ Universitas Islam Negeri Sunan Kalijaga Yogyakarta, Indonesia \\ E-mail: ustadih@yahoo.com
}

\begin{abstract}
Identity is the basic principle of the society. The search for identity and effort to build and defend identity is the fundamental struggle for society. Theoretically, the prosperous society depends on the strength of its identity. The society can achieve the social advancement, extraordinary ethos, and creativity because of their strong identity. This article attempts to explain how identity and self-capability contribute to the social advancement. This explanation refers to the thought of the modern gigantic Turkish thinker, Bediuzzaman Said Nursi. Exploring the construction of Said Nursi's concept of Islamic identity and self-capability in developing society, especially in social prosperity and economic progression, this paper attempts to explain the foundation of social and individual prosperity. According to Said Nursi, the development of culture and civilization will be established by powerful identity which constructed by awareness of collective personality (sahs- $\iota$ manevi). The powerful identity, therefore, bases on the spirit of self-capability that will raise a progress and development. Referring to Said Nursi, this basic foundation of selfcapability developed through three principles, namely selfinterest versus self-sacrifice, extravagance versus frugality, and greed versus contentment. Then, by practicing and applying these three values, the prosperity and development can be achieved.
\end{abstract}

Keywords: Bediuzzaman Said Nursi; identity and selfcapability; social advancement.

\section{Pendahuluan}

Abad kedua puluh merupakan abad peralihan kondisi umat Islam, dari kondisi yang berada di bawah penjajahan menuju kondisi yang bebas dan merdeka. Tantangan terberat yang dihadapi oleh umat 
Islam di manapun berada, termasuk di Indonesia, adalah penyesuaian dengan iklim sosial, ekonomi, dan psikologis yang sangat berat. Ketika sebuah bangsa terjajah, maka sebagian besar tergantung pada sistem kolonial yang sedikit banyak terarah pada pengembangan sosial ekonomi yang baik-meskipun dalam kapasitas dan perspektif kolonial. Ketika telah merdeka umat Islam harus menyusun satu sistem sosial, budaya, dan ekonomi secara mandiri. Hambatan utama adalah "warisan" imperialized mentality dari umat Islam belum sepenuhnya hilang. Justru ketika lepas dari penjajahan persoalan identitas sebagai bangsa yang merdeka sulit dipertegas, karena bangsa tersebut akan "mewarisi" tradisi sebagai bangsa terjajah. Hal ini berimplikasi pada krisis identitas, kemadirian sebagai bangsa, dan etos kerja yang lemah.

Di berbagai bangsa dan negara yang umat Islam hidup telah muncul tokoh-tokoh yang berusaha membangkitkan identitas, kemadirian, dan etos kerja dengan memikirkan serta membangun konsep dan sistem yang baik. Misalnya di Indonesia lahir tokoh-tokoh besar yang mempunyai pemikiran yang brilian untuk menjadikan bangsa Indonesia mandiri setelah lepas dari penjajahan. Mereka membangun dan mengembangkan gagasan kemajuan bagi bangsa Indonesia. Hal serupa juga terjadi di berbagai negara di seluruh dunia selepas dari penjajahan bangsa Eropa. Turki misalnya-dengan karakter yang serupa dengan Indonesia, yakni pernah mempunyai sebuah imperium besar yang bisa menguasai wilayah yang sangat luas; memiliki karakter kuat sebagai bangsa dengan menciptakan bahasa, tulisan, dan budaya sendiri; sama-sama dijajah oleh bangsa Eropa; mempunyai etos keislaman yang sama-sama kuat; dan melahirkan pemikir-pemikir yang berpengaruh di dunia-juga memiliki pemikiran yang brilian untuk kemajuan bangsanya.

Setelah puluhan tahun membangun dengan konsep pemikiran yang ditelorkan oleh para pemikir dan penggagas konsep itu, ada bangsa yang dapat memperoleh kemajuan yang baik dengan standar kemakmuran dan pemerataan kemakmuran rakyatnya, namun ada bangsa yang belum bisa mencapai kemajuan tersebut. Ragam kegagalan ini tentu saja tidak serta merta disebabkan karena pemikiran para penggagas itu kurang visioner atau terlalu lemah, tetapi ada faktor kesiapan mental dari sebuah bangsa untuk bergerak maju belum terbangun dengan baik, atau ada upaya pihak lain dari luar yang secara sengaja memperlemah kemampuan sebuah bangsa untuk maju. 
Ini semua kembali pada "sikap mental" bangsa tersebut untuk memperoleh kemajuan.

Untuk memperoleh kembali gagasan yang mendorong pada kemajuan maka harus ada upaya menggali kembali nilai-nilai dasar bangsa tersebut, menyegarkan pemahaman pada gagasan mulia para pemikir awal bangsa, dan mencari referensi pemikiran baru yang bisa mengantarkan pada kemajuan yang telah diparktikkan oleh sebuah bangsa di luar bangsa kita sendiri. Dengan kata lain, harus "mengaji"-benchmarking, pada bangsa lain yang memiliki karakter serupa dengan dengan bangsa sendiri untuk maju. Sekali lagi hal ini bisa dilakukan dengan kembali menata sikap mental.

Secara teoretis David McClelland, seorang psikolog sosial dari Amerika, melihat bahwa kemajuan dan kemunduran sebuah masyarakat memang banyak ditentukan oleh sikap mental masyarakatnya. Untuk memperoleh kemajuan, terdapat suatu sikap mental yang wajib dimiliki oleh sebuah bangsa yakni need for achievement (kebutuhan akan capaian-capaian tertentu)-yang secara teknis McClelland menuliskan dengan $n$-Ach virus (virus untuk kemajuan). ${ }^{1}$ Virus ini menjadi penyebab jiwa yang neurotik, yakni sebuah dorongan untuk selalu mencapai "produk-produk" modernisme. Kehendak untuk selalu "mencapai", need for Achievement (n-Ach), menjadi apa yang dikatakan Edward Shils dengan "kehendak-untukmenjadi-modern". Dengan asumsi bahwa modern adalah meninggalkan yang "kuno", pada gilirannya kehendak untuk menjadi modern merupakan manifestasi dari kehendak untuk mengeliminir pandangan primordial pra-modern. Asumsi-asumsi ini akan selalu menjadi "ideologi" orang modern, yang pada saatnya nanti akan dijadikan "alat" untuk menguasai orang lain dengan agen-agen modernitas, seperti ilmu dan teknologi. ${ }^{2}$ Melalui proyek-proyek modernisasi,

\footnotetext{
${ }^{1}$ Lihat selengkapnya uraian tentang istilah ini dalam David C. McClelland, "The Impulse to Modernization", dalam Myron Weiner (ed.), Modernization: The Dynamics of Growth (Cambridge, Mass.: VOA Forum Lectures, 1966), 29-40; bandingkan dengan tulisannya yang lain dalam David C. McClelland, The Achieving Society (Princenton, N.J.: O. Van Nostrand Company, 1961). Alberto Martinelli lebih menegaskan bahwa modernisasi lebih terfokus pada capaian material berupa ertumbuhan ekonomi sampai pada level global yang juga dipengaruhi oleh $n$-Ach virus tersebut; lihat Alberto Martinelli, Global Modernization: Retbinking the Project of Modernity (London: Sage Publication, 2005), 36.

2 Myron Weiner (ed.), Modernization: The Dynamics of Growth. Cambridge (Mass.: VOA Forum Lectures, 1966), 210.
} 
manusia menjadi teralienasi dalam kungkungan teknokrasi, dan hanya menjadi l'bomme machine. ${ }^{3}$

Ketika pandangan modernitas dilihat manifestasinya dalam kehidupan sekarang akan menampakkan sosoknya yang sebenarnya, yakni penghalauan emosi dan kesadaran menuju pada apa yang disebut oleh Baudrillard dengan "kesadaran masyarakat yang diam". Artinya, modernitas akan mempertontonkan kemajuannya yang dapat "membungkam" kesadaran manusia untuk "tunduk" pada kemauan modernitas.

Produk-produk modernitas disajikan dengan teknologi yang canggih, yang dengannya pula konsumen digiring pada "kesadaran yang terkuasai", imperialized mentality. Ikon-ikon budaya itu hanyalah satu pencitraan atas sebuah budaya yang besar (great tradition) yang secara tidak sadar membentuk bangunan kesadaran manusia yang "mengabdi" pada modernitas tersebut. Pencitraan itulah yang akhirnya membentuk image of $n$ - $A$ ch sebagaimana yang telah disebut di atas. Fenomena ini semakin mengukuhkan betapa modernitas, menurut Arthur Kroker dan David Cook, telah menciptakan kekuasaan baru atas manusia yang menciptakan modernitas itu sendiri. $^{5}$ Gejala modernitas yang materialistik ini sebagai sebuah gelombang besar yang menerpa apa saja yang dilaluinya, yang dalam istilah teknis disebut dengan juggernaut.

Anthony Giddens menjelaskan bahwa, juggernaut merupakan sebuah kendaraan besar yang menghancurkan semua yang dilaluinya tanpa ada yang melawan, dan semua orang akan masuk dalam kendaraan atau gelombang tersebut. ${ }^{6}$ Fenomena inilah yang meniscayakan sebuah gelombang globalisasi yang "tanpa ampun" menguasai kesadaran "manusia modern". Meskipun McClelland sendiri mengantisipasi konsekuensi dari sikap mental ini dengan kemajuan "tanpa batas" yang meninggalkan aspek humanitas, namun

\footnotetext{
3 L'bomme machine merupakan sebuah konsep untuk menggambarkan manusia modern yang telah kehilangan kemanusiaannya karena "tersandera" oleh ruangruang modernisme dengan kondisi kesadaran yang hanya memenuhi tuntutan kemodernan tanpa melihat jati dirinya. Lihat selengkapnya Jacques Ellul, The Technological Society (New York: Vintage Book, 1964).

${ }^{4}$ Jean Baudrillard, In the Shadow of Silent Majorities or the End of Social and Other Essays, terj. Paul Fross, John Johnston, dan Paul Patton (New York: Semiotext[e]. 1983), 19.

5 Arthur Kroker dan David Cook, The Postmodern Scene, Experimental Culture and Hyper-Aesthetics (N.Y.: Mcmillan, 1988), 271.

${ }^{6}$ Anthony Giddens, The Consequences of Modernity (Oxford: Polity Press, 1990).
} 
dia menegaskan bahwa mentality menjadi acuan utama untuk maju. Kalau kembali pada topik awal mengenai "kesadaran untuk maju", maka harus menggeser imperialized mentality dengan sikap mental untuk maju, melalui kesadaran need for achievement tersebut.

Untuk konteks kita, bangsa Indonesia, kalau mengaca pada kemajuan bangsa lain maka perlu upaya-upaya kultural yang strategis dalam membangkitkan semangat dan etos untuk maju, yakni mempertegas identitas dan membangun kemandirian sebagai bangsa. Dalam konteks ini tidak ada buruknya menengok "sahabat" di luar yakni bangsa Turki. Bukan bermaksud membandingkan, tetapi belajar bersama sebagai bangsa Muslim dalam membangkitkan identitas dan kemandirian bangsa sehingga mampu bersaing dan duduk sejajar dengan bangsa-bangsa Eropa. Pada acara Sail Morotai tahun 2012, sebagai kelanjutan dari KTT APEC ke 26 di Vladivostok Rusia, Turki bersama Indonesia dan negara-negara MIST (Mexico-IndonesiaSouth Korea-Turki) berada pada jajaran negara dengan tingkat pertumbuhan ekonomi yang cepat. Turki mencapai $6 \%$ dan Indonesia $6,3 \%{ }^{7}$

Kemajuan Turki sampai saat ini salah satunya ditopang oleh kuatnya "gagasan ideal" para pemikir bangsa itu dalam membangun mentalitas bangsanya. Menurut Serif Mardin, visiting professor dalam bidang social sciences di berbagai universitas di USA dan Inggris, perubahan radikal struktur pemikiran bangsa Turki sejak merdeka dari penjajahan Eropa adalah hadirnya pemikiran tokoh, salah satunya Bediuzzaman Said Nursi. Penelitian Mardin yang dilakukan berpuluh tahun yang kemudian diterbitkan dengan judul Religion and Social Change in Modern Turkey: the Case of Bediuzzaman Said Nursi telah menunjukkan hal itu. ${ }^{8}$ Terlihat untuk era sekarang ini, secara ekonomi Turki, demikian juga Indonesia, mampu bersaing dengan negaranegara maju di dunia.

Dari penelitian itu, Mardin menandaskan bahwa mentalitas yang dibangun oleh bangsa Turki modern didasarkan pada kemandirian dan identitas yang kuat. Semangat ini pada akhirnya diteruskan oleh

7 Firmanzah, "Morotai dan APEC 2013", dalam http://www.setkab.go.id/artikel5725-.html, diakses 22 Desember 2012, pukul 22.50 WIB.

${ }^{8}$ Untuk hal ini silahkan lihat Şerif Mardin, Religion and Social Change in Modern Turkey: The Case of Bediuzzaman Said Nursi (Albany: State University of New York (SUNY) Press, 1989); juga bandingkan dengan karyanya yang lain, Şerif Mardin (ed.), Culture Transitions in The Middle East (Leiden: E.J Brill, 1994); dan Şerif Mardin, "Religion in Modern Turkey”, International Social Science Journal, Vol. 29, No. 2 (1977). 
gerakan-gerakan kultural, seperti Said Nursi dan para penerusnya yang terwadahi dalam Nurculuk (Nur Movement) yang bergerak dalam bidang intelektual, spiritual, dan budaya. Satu sayap lain dari gerakan kultural yang bersumber dari pemikiran Said Nursi yakni gerakan yang dipelopori oleh Fethullah Gülen dalam Gülen Movement yang berkecimpung dalam dunia pendidikan, sosial, dan budaya. Untuk konteks ini, gambaran tentang pemikiran Said Nursi mengenai identitas dan kemandirian sebagai bangsa dalam menyongsong kemajuan sangat penting untuk dielaborasi, dan tulisan berikut ini ingin mencoba menjabarkan bagaimana gagasan seorang pemikir Turki dalam memberikan fondasi bagi kemajuan sebuah bangsa setelah lepas dari penjajahan bangsa lain. Kemudian, sebagai replikasi, bagaimana pemikiran itu dapat dijadikan referensi dan pengayaan bagi kemajuan bangsa Indonesia tanpa mengesampingkan potensi-potensi sendiri dari pemikiran para tokoh kemajuan di Indonesia yang telah ada sebelumnya.

\section{Sketsa Intelektual Bediuzzaman Said Nursi}

Sebagaimana telah diketahui bahwa masa kehidupan Said Nursi dilatarbelakangi oleh kondisi sosial yang sangat beragam, dari era akhir kesultanan Turki Usmani, Era Penjajahan, dan Era Kemerdekaan. Kondisi inilah yang membentuk pola pemikiran yang membangkitkan semangat untuk maju. Era akhir kesultanan Usmani dan era-era setelahnya telah memberikan gambaran suram tentang masa depan Turki, karena kontrol sosial-budaya yang lemah dengan kecenderungan westernisasi yang kuat dari elit-elit Turki. Kecederungan ini akhirnya melahirkan revolusi yang memberikan landasan munculnya gerakan sekularisasi. Sekularisasi yang menjadi ideologi di Turki telah menempatkan bangsa ini kehilangan identitas untuk maju. Kemajuan, bagi pengikut sekularisme, ditentukan bagaimana berkiblat ke negara-negara Barat, bukan pada bagaimana bisa bangkit dengan kekuatan dan potensi sendiri untuk membangun bangsa. Tidak salah jika Niyazi Berkes melukiskan bagaimana sekularisme ini telah membentuk Turki sebagai bangsa yang tidak mempunyai pegangan dalam kehidupan karena telah menghilangkan identitas utama, yakni Turki yang Islam. ${ }^{9}$ Kemajuan yang signifikan baru bisa didapatkan oleh Turki pada sepuluh tahun terakhir sejak

${ }_{9}$ Lihat selengkapnya ulasan mengenai hal ini di Niyazi Berkes, The Development of Secularism in Turkey (Montreal: McGill University Press, 1964). 
tahun 1990an sejak pemerintahan sipil yang mengusung nilai-nilai Islam sebagai landasan kemajuan. ${ }^{10}$

Lebih lanjut menurut Ihsan Daği, Islam telah mengembalikan Turki sebagai bangsa yang mempunyai identitas yang kuat dengan memegang teguh sistem politik, ekonomi, sosial, dan budaya yang didasarkan pada nilai-nilai Islam yang telah dimanifestasikan oleh kesultanan Usmani di era sebelumnya. ${ }^{11}$ Sebagai identitas, Islam telah memberikan orientasi baru bagi perkembangan bangsa Turki. Sejak naiknya partai yang berhalauan Islam sebagai pemegang tampuk pimpinan Turki-Welfare Party/Refah Partisi (Necmetin Erbakan) di era 1980an dan Justice and Development Party/Adalet ve Kalkinma Partisi [AKP] (Recep Tayyib Erdogan) di era 1990an, identitas bangsa yang kuat mengantarkan Turki menjadi bagian dari European Community (EC). Duo Erdoğan dan Abdullah Gül sebagai pemegang tampuk pimpinan Turki modern telah membawa bangsa ini pada kemandirian untuk maju. Di tengah perkembangan ekonomi politik dunia yang demikian hegemonik, Turki membangun kemandirian yang baik dalam menciptakan kemakmuran dan kesejahteraan rakyatnya ${ }^{12}$ berdasarkan kesadaran identitas Islam dan nasionalisme Turki yang kuat yang terkenal dengan konsep Milli Görüss. Satu hal yang menarik dari konsep ini adalah Islam sebagai identitas tidak dimasukkan dalam agenda politik, tetapi merupakan bagian dari identitas sosial dan budaya nasional. Bilal Sambur, seorang intelektual Turki, menulis:

AKP defines its political identity as the Conservative Democracy, which makes Islam not apart of its political agenda, but a part of socialcultural identity. The vocabulary of AKP's conservative democracy belongs to the mainstream of political discourse. ... Instead of an Islamist agenda, it tries to syntetize conservative values, such as morality, national identity, historical pride and so on, with democracy, free market economy, pluralism, the rule of law and human rights. AKP changes itself in liberal and progressive direction, at the same time it shows sensitivity about the importance of the maintaining Turkish national, cultural and religious identity and values in Turkish context. ${ }^{13}$

${ }^{10}$ Lihat selengkapnya uraian ini dalam Bilal Sambur, "The Great Transformation of Political Islam in Turkey: The Case of Justice and Development Party and Erdogan", European Journal of Economic and Political Studies (2), 2009.

11 Ihsan D. Dagi, "Transformation of Islamic Political Identity in Turkey: Rethinking the West and Westernization", Turkish Studies, Vol. 6, No. 1 (2005), 6-7.

12 Bilal Sambur, "The Great Transformation", 121.

${ }^{13}$ Ibid. 
Apa yang dilakukan oleh para pemimpin dan bangsa Turki merupakan kelanjutan dari proses yang telah berjalan sebelumnya. Gerakan yang telah berlangsung di Turki yang disebut dengan "social Islam" ini, merupakan manifestasi dari aplikasi nilai Islam dalam konteks sosial. Proses ini dipelopori oleh sebuah gerakan yakni nurcu-gerakan Nur (Nur Movement), yakni gerakan yang diinspirasi dan dimotori oleh pemikiran Said Nursi. ${ }^{14}$ Nurculuk merupakan gerakan dari murid-murid Bediuzzaman Said Nursi untuk menyebarkan ide-ide Islam modern yang menyatu dengan kemajuan zaman tanpa larut dalam westerisasi. Nilai-nilai barat yang diakomodasi adalah aspek positifnya seperti keterbukaan, demokrasi, disiplin, dan penghargaan terhadap orang lain. Sementara nilai-nilai yang negatif seperti sekularistik, superior, hegemonik, dan individualistik ditinggalkan. Dengan kata lain, Barat diterima dalam konteks tertentu dan ditolak dalam konteks tertentu pula.

Sebagai sebuah gerakan, Nurculuk merupakan subjek yang dinamis yang bergerak menuju ke depan. Eric Hobsbawn, seorang pemikir Marxis, dalam bukunya The Archaic Form of the Social Movement menjelaskan bahwa sebuah gerakan meniscayakan adanya basis nilai untuk tujuan-tujuan jangka panjang ke depan. ${ }^{15}$ Sejalan dengan Hobsbawm, Davis mengungkapkan bahwa sebuah gerakan sosial akan mentransformasikan gagasan-gagasan mereka untuk merubah cara pandang masyarakat itu. ${ }^{16}$ Gagasan-gagasan tersebut pada gilirannya akan mendeterminasi sikap dan tindakan masyarakat pada umumnya. Manuel Castells dalam bukunya The City and the Grassroots menyatakan bahwa sistem gagasan yang ditransformasikan dalam konteks masyarakat "bawah" atau yang lazim dikenal dengan grassroot-yakni sebuah kesadaran umum yang dianut oleh sebagian besar masyarakat, akan memberikan "makna" bagi keberlangsungan masyarakat tersebut. ${ }^{17}$

14 Kemal Karpat, "Nurculuk", "Nursi", dalam C.E. Bosworth et.al (eds.), The Encyclopaedia of Islam, Vol. 3 (Leiden: E.J Brill, 1995), 143-145.

15 Eric Hobsbawn, Primitive Rebel: The Archaic Form of the Social Movement in the Nineteenth and Twentieth Centuries (New York: W.W. Norton and Company, Inc., 1965).

16 Gerald F. Davis et al., Social Movements and Organization Theory (Cambridge: Cambridge University Press, 2005).

${ }_{17}$ Manuel Castells, The City and the Grassroots (London: Edward Arnold (Publisher) Ltd., 1983). 
Dalam konteks ini, Nurçuluk merupakan sebuah gerakan sosial keagamaan yang mempunyai dampak bagi perubahan sosial bagi masyarakat pada umumnya. ${ }^{18}$ Nurculuk mempunyai gagasan-gagasan pokok mengenai kehidupan manusia secara umum. Gagasan-gagasan tersebut ditransformasikan dalam konteks kehidupan di Turki. Namun, ketika pada periode-periode awal gerakan Nurçuluk menemui banyak resistensi dengan penguasa Turki, maka gerakan ini kemudian menyebar ke luar Turki. Penyebaran di luar Turki tidak saja mentransformasi gagasan pemikiran intelektual Islam, tetapi juga mentransformasikan Islam yang maju yang dapat berinteraksi aktif dengan dunia "modern".

Gagasan Islam yang ditransformasikan oleh gerakan Nurculuk adalah Islam yang maju, Islam yang dapat diterima dan mewarnai kehidupan warga dunia (kosmopolit). Berbagai pemikiran Islam yang kosmopolit itu merupakan interpretasi dari gagasan-gagasan pemikiran Islam Said Nursi dalam Risale-i Nur. Bidang-bidang yang dikaji oleh Nurcu meliputi bermacam-macam aspek dalam kehidupan baik dalam politik dan pemerintahan, sosial budaya, sains dan filsafat, serta ajaran tasawuf dalam konteks dunia "modern".

Dalam konteks politik dan demokrasi, gerakan Nurçuluk cenderung pada kehidupan berpolitik yang "berasaskan" pada kesadaran kebangsaan. Sebagai penerus dari pemikiran Said Nursi, gerakan Nurculuk memberikan penekanan pada kesadaran kebangsaan, sehingga kehidupan politik yang berdasarkan pada khiläfah tidak menjadi prioritas dalam pemikirannya. Negara merupakan sebuah alat untuk mengaplikasikan ajaran sharī'ah Islam, jadi bukanlah tujuan. Intinya, apa pun bentuk sistem pemerintahan bukan hal yang signifikan, namun yang terpenting adalah berlakunya sharíah Islam di negara itu dengan baik.

Dengan demikian kesadaran kecintaan kepada negara-bangsa merupakan sebuah tindakan dalam rangka mengamalkan ajaran sharī'ah Islam. Sharī'ah sendiri dipahami bukan sebagai seperangkat aturan yang sempit yang merujuk pada salah satu pandangan mazhab tertentu, namun sebagai sebuah "sistem tindakan" etis yang berdasarkan al-Qur'ān dan sunah Rasulullah. Oleh karena itu, menurut Said Nursi nasionalisme terbagi menjadi dua bagian, yakni nasionalisme positif dan nasionalisme negatif.

18 Şerif Mardin, Religion and Social Change in Modern Turkey: The Case of Bediüzzaman Said Nursi (California: SUNY Press, 1989). 
Nasionalisme positif merupakan sebuah kesadaran cinta negarabangsa yang dijadikan sarana bagi para warganya untuk menyatukan berbagai macam perbedaan yang ada di dalam sebuah negara. Dengan demikian kesadaran ini membutuhkan etos persaudaraan, cinta, dan keikhlasan. Ragam perbedaan yang terdapat dalam sebuah negarabangsa merupakan sebuah kesatuan. Melalui cara pandang seperti ini kesadaran nasionalisme tidak akan menimbulkan permusuhan, perang, dan sentimen antar-golongan dan kelompok yang meruncing. Nasionalisme yang menjadi penyebab munculnya berbagai sentimen antar golongan dan kelompok merupakan nasionalisme negatif.

Negative nasionalism merupakan sebuah "kecintaan" terhadap negara yang dijadikan sebagai tujuan itu sendiri. Dengan demikian kecintaan pada negara-bangsa tersekat pada kecintaan pada kelompok-kelompok tertentu yang berada di dalam sebuah negara tersebut. Misalnya, nasionalisme bangsa-bangsa Eropa dibangun di atas kesadaran atas kecintaan pada ras tertentu, identitas spesifik tertentu sebagaimana nasionalisme Inggris Raya bagi ras England, Scotland, dan Irlandia. Contoh yang lain lagi, nasionalisme Jerman tersekat pada ras Jerman saja, begitu juga nasionalisme Perancis, Belanda, dan lain sebagainya. Kecintaan pada negara-bangsa tersebut didasarkan pada kecintaan pada ras dan kesukubangsaan.

Rasialisme dan tribalisme-sebagaimana disebutkan di atasmenjadi ukuran kesatuan dan kecintaan pada neraga-bangsa. Kesadaran tersebut berorientasi pada sikap mau bersatu bila mempunyai kesamaan ras dan asal-usul. Dengan demikian apabila terjadi gesekan sedikit antar ras dan suku bangsa akan timbul permusuhan yang panjang. Dengan kesadaran dan sikap seperti tersebut ini, maka menurut Said Nursi, nasionalisme positif menjadi nilai ideal bagi sebuah kehidupan berbegara dan berbagsa. ${ }^{19}$

Dalam konteks inilah gerakan Nurculuk mentransformasikan nilainilai keislaman bagi kehidupan umat Islam dan manusia pada umumnya di mana pun mereka berada. Melalui konsep kesadaran kebangsaan ini, maka sistem pemerintahan apapun yang berlaku dalam sebuah negara bukan menjadi persoalan bagi gerakan Nurculuk. Prinsip yang dipegang oleh para Nurcu adalah Islam yang maju dan modern yang berlaku dalam sebuah negara tersebut, sehingga tidak mempersoalkan sistem pemerintahannya. Dengan dasar ini pula, gerakan Nurçuluk akomodatif terhadap sistem demokrasi.

${ }^{19}$ Nursi, The Letters, $26^{\text {th }}$ Letter, $3^{\text {rd }}$ Topic, 381-385. 
Dalam sebuah negara, Islam yang damai selalu diperjuangkan oleh gerakan Nurculuk. Bagi mereka, memenangkan Islam bukan dengan jalan revolusi dengan merubah sistem pemerintahan secara frontal dan menggunakan kekerasan, namun dengan melakukan reformasi kesadaran yakni memanggil orang satu persatu untuk kembali pada "spiritualitas" dan membebaskan mereka dari kesadaran yang materialistik. Para Nurcu mengaktualisaikan jihad sebagai cibad-i manevi (jihad maknawi, jihad dengan kata-kata) yakni jihad dengan membangkitkan kesadaran dan perbuatan. Dalam menghadapi kemerosotan moral-spiritual tidak dapat dihadapi secara fisik, tetapi mereka menggunakan "kata-kata" yang baik-lisan maupun tulisan, dan dengan tindakan yang bermoral. ${ }^{20}$ Sikap ini kemudian dikenal dengan istilah yang sangat fenomenal yakni hizmet (pelayanan yang baik) dan müspet (kesadaran dan sikap yang baik).

Berdasarkan pola pemikiran dan kesadaran itu, gerakan Nurçuluk di mana pun berada selalu menekankan kedamaian dan menghargai perbedaan. Oleh karena itu, mereka selalu menghindarkan diri dari konsep "revolusi" karena akan menimbulkan perbuatan anarkis. Perbuatan anarkis merupakan cerminan dari sikap yang bertentangan dengan keimanan dan spirit keislaman yang tinggi. Kesadaran dan sikap ini selalu dimulai dari dershane dengan segala aktifitasnya.

Islam dewasa ini menghadapi perubahan yang cepat berkaitan dengan kemajuan zaman yang cepat pula. Kemajuan zaman yang dihadapi oleh dunia sekarang adalah produk dari pemikiran dan peradaban Barat. Dalam konteks ini, Nurçuluk mengapresiasi kemajuan Barat sebagai bagian dari kemajuan umat Islam sepanjang tidak bertentangan dengan nilai-nilai dasar Islam seperti ketauhidan dan moralitas.

Pandangan Nurçuluk ini didasarkan pada pemikiran Said Nursi terhadap peradaban Barat. Menurut Said Nursi peradaban Barat itu terbagi menjadi dua bentuk, bentuk pertama peradaban Barat yang bersumber dari filsafat Materialisme sehingga melahirkan sebuah kesadaran yang tidak menghargai kemanusiaan, dan melahirkan peperangan yang tidak berkesudahan. Said Nursi menyatakan:

Mestinya tidak usah disalahpahami, bahwa Eropa terbagi menjadi dua. Salah satunya menawarkan kemajuan ilmu pengetahuan (sains) yang memberikan jaminan terhadap keadilan, dan hak asasi

20 Söler Publications, Jihad of the Word and Positive Action: Bediuzzaman Said Nursi's Interpretation of Jihad in the Modern Age (Istanbul: Söler Publications, t.th.), 1-14. 
manusia, serta kemajuan tekonolgi industri-industri yang memberikan manfaat bagi kehidupan masyarakat; yang terilhami oleh ajaran Kristen yang murni. Eropa yang pertama ini yang saya kehendaki. Adapun Eropa yang kedua adalah Eropa yang menumbuhkan kejahatan dan kedurhakaan yang ditimbulkan oleh pemikiran filsafat Naturalisme yang menganggap kejahatan terhadap sebuah peradaban sebagai suatu hal yang benar. ${ }^{22}$

Pandangan ini memungkinkan penerimaan dan transformasi yang baik atas sistem sosial dan budaya dari Barat. Oleh karena itu, penampilan para Nurcu bukan seperti cara hidup orang yang tinggal di dunia Arab, melainkan seperti orang Eropa. Penerimaan ini merepresentasikan kesadaran akan cara hidup yang maju mengikuti cara pandang mereka pada Eropa dan Barat dengan berbagai kemajuannya. Sekalipun demikian, Islam merupakan jiwa bagi para Nurcu.

Secara simultan, gerakan Nurculuk menjadikan kesadaran dan sikap tersebut di atas sebagai "jalan hidup". Dengan demikian, mentransformasikan kesadaran Islam yang kosmopolit yakni Islam yang telah menjadi agèman (sistem hidup) bagi dunia melalui kajiankajian terhadap pemikiran Said Nursi merupakan cara-cara hidup bagi Nurçuluk baik di Turki maupun di luar Turki.

Para murid itu meyebarkan karya-karya Said Nursi yang ditulis pada era akhir kesultanan Usmani, Era Revolusi, dan Era Kemerdekaan dan kemudian diterbitkan dengan judul Risale-i Nur (risalah-risalah cahaya). Pemikiran Said Nursi yang disebarkan oleh murid-muridnya telah memberi inspirasi bagi generasi Turki kontemporer yang dipopulerkan oleh tokoh terkemuka Fethullah Gülen. Gagasan-gagasan keislaman Said Nursi diterjemahkan dalam konteks sosial oleh Fethullah Gülen_-sebagai salah satu penerus Said Nursi, ${ }^{23}$ dan juga murid-murid yang lain dari jalur Mustafa Sungur di bidang dersane (madrasah), budaya, dan intelektual. Islam yang ditampilkan oleh para murid Said Nursi telah memberi warna bagi perkembangan Turki untuk maju.

\section{Signifikansi Identitas dan Kemandirian Umat}

Sebagaimana telah disebutkan di atas bahwa kemajuan bangsa Turki khususnya, dan capaian-capaian yang telah diraih oleh bangsa-

22 Bediüzzaman Said Nursi, Lem'alar (İstanbul: CD ROM Risale-i Nur 1.0, t.th.), 643.

${ }^{23}$ M. Hakan Yavuz, "Towards an Islamic Liberalism? The Nurcu Movement of Fettullah Gulen”, Middle East Journal, Vol. 53, No.4 (1999), 584-605. 
bangsa muslim lainnya umumnya telah mengantarkan pada pergaulan dunia global. Gelombang globalisasi telah memposisikan bangsabangsa muslim berada pada sebuah "empire". ${ }^{24}$ Hal ini terjadi sejak bangsa-bangsa Muslim berada akhir era kolonialisme hingga saat ini. Tantangan terberat dari bangsa bekas terjajah adalah mentalitas yang belum stabil, kecuali kalau mempunyai kemauan kuat membangun jati diri bangsanya, sehingga nilai-nilai kemandirian belum juga terbangun dengan baik. Untuk konteks inilah, sebagaimana telah disebutkan di atas, pemikiran Nursi tentang kemandirian umat/bangsa sangat signifikan dikemukakan.

Satu hal yang menjadi perhatian Nursi adalah westernisasi yang kemudian melahirkan globalisasi. Akibat dari globalisasi bagi umat Islam adalah hilangnya spiritualitas, hal ini dikarenakan globalisasi menghendaki sebuah tatanan "tunggal" dengan tanpa mempertimbangkan situasi sosiologis dan psikologis lokal setiap bangsa. Selanjutnya, dengan keasadaran global yang telah dibangun, maka sebuah bangsa/umat akan kehilangan jati dirinya. Kesadaran ini akan menuntun pada pola "peniruan" atas budaya lain dengan mengesampingkan tradisi luhur bangsa sendiri. Tindakan imitasi atas budaya asing pada gilirannya akan "menipu" kesadaran sendiri untuk bisa maju memanfaatkan potensi sendiri yang telah ada sebelumnya. Oleh karena itu, Nursi menulis:

O sons of this land! Do not try to imitate Europeans! How can you reasonably trust in and follow the vice and invalid, worthless thought of Europe after the boundless tyranny and enmity it has shown you? No! No! You who imitate them in dissoluteness, you are not following them, but unconsciously joining their ranks and putting to death both yourselves and your brothers. Know that the more you follow them in immorality the more you lie in claiming to be patriots! Because your following them in this way is to hold your nation in contempt, to hold the nation up to ridicule! $!^{25}$

Selanjutnya, perilaku imitasi pada hakikatnya merupakan bentuk "penipuan" terhadap diri sendiri, sehingga kepekaan terhadap

\footnotetext{
${ }^{24}$ Menurut Michael Hardt dan Antonio Negri, empire di sini dimaksudkan sebagai sebuah tatanan tunggal dengan satu aturan tungga juga. Empire diartikan sebagai a series of national and supranational organism united under a single logic of rule. Untuk konteks ini globalisasi telah berperan sebagai empire tersebut. Lihat selengkapnya Michael Hardt dan Antonio Negri, Empire (Cambridge: Harvard University Press, 2001), xii.

${ }^{25}$ Said Nursi, The Flashes Collection, terj. Şukran Vahide (İstanbul: Sözler Neşriyat, A.Ş., 2000 [1995]), 166.
} 
kemampuan dan kemandirian akan tumpul. Dalam hal ini Nursi menulis:

Individuals who resemble one another may imitate one another, those of the same kind may take on one another's forms, those who are close to one another in rank or status may imitate one another and temporarily deceive people, but they cannot do so for ever. For in any event, the falseness and artificiality in their behaviour will show up their imposture to the observant, and their deception will not last. If the one who is attempting to imitate another under false pretences is quite unlike them, for example, if an uneducated man wants to imitate in learning a genius like Ibn-i Sina, or a shepherd assume the position of a king, of course, they will not deceive anyone at all, they will only make fools of themselves. Everything they do will proclaim, "This is an impostor. ${ }^{26}$

Bentuk imitasi ini menggejala di dunia sebagai bentuk lain dari globalisasi yang pada gilirannya akan mengantarkan pada apa yang disebut dengan "empire" itu. Marshall McLuhan mengatakan bahwa semangat barat yang mengusung globalisasi akan mengantarkan dunia pada "satu" entitas yang disebut dengan global village, yakni sebuah "kampung" yang mewadahi seluruh entitas dan menyatu di dalamnya. Ini terjadi ketika globalisasi menjadi pilihan bagi manusia dan media telah menjadi sarana interaksi antar-subjek. ${ }^{27}$ Subjek menjadi luruh menjadi satu, yakni masyarakat "massa", dan kahir dari perjalanan masyarakat massa adalah mayoritas yang diam (silent majority) yakni sebuah masyarakat yang tidak lagi kritis, kehilangan identitas dan jati diri, imperialized mentality, dan objek bagi dirinya sendiri. Terkait dengan hal ini Jean Baudrillard menggambarkan kondisi masyarakat massa seperti ini sebagai berikut:

The mass absorbs all the social energy, but no longer refracts it. It absorbs every sign and every meaning, but no longer reflects them. It absorbs all messages and digests them. For every question put to it, it sends back a tautological and circular response ... The mass is dumb like beasts, and its silence is equal to the silence of beasts. Despite having been surveyed to death ... it says neither whether the truth is to the left or to the right, nor whether it prefers revolution or repression. It is without truth and without reason. It

\footnotetext{
${ }^{26}$ Said Nursi, The Words, terj. dari 'Sözler' oleh Sukran Vahide (İstanbul: Sözler Neşriyat, Ticaret ve Sanayi, A.Ş., 1992), 201.

27 Marshall McLuhan, Understanding Media: The Extensions of Man (New York: McGraw-Hill Book Co., 1964).
} 
has been attributed with every arbitrary remark. It is without conscience and without unconscious. ${ }^{28}$

Globalisasi dan perkembangan kontemporer selalu meniscayakan suborninasi bagi siapa saja yang tidak sejalan dengannya. Nursi menggambarkannya sebagai berikut:

Up to the present, Muslims have not entered this present civilization voluntarily, it has not suited them, moreover it has clamped on them fetters of bondage. While it should be the cure for mankind, it has become poison. It has cast eighty per cent into penury and misery, and produced a false happiness for ten per cent. The remaining ten per cent it has left uneasily between the two. Commercial profits have been the tyrannical minority's. But true happiness is happiness for all; Or at least salvation for the majority. ${ }^{29}$

Dengan demikian, apa yang dikatakan Nursi tentang "present civilization" akan menjadikan manusia sebagai objek bagi diri sendiri sebagaimana telah disiggung di atas. Oleh karena itu, untuk menyikapi hal ini Nursi memberikan sebuah gambaran bahwa kesadaran manusia akan memperoleh posisi yang baik jika kembali pada kesadaran asal manusia itu sendiri yakni kolektivitas (jamä $\mathbf{c})$. Hal ini dikarenakan oleh sifat dasar globalisasi yang melahirkan individualitas yang sangat tinggi, meskipun berkumpul sebenarnya terpisah, bisa diibaratkan seperti tumpukan beras yang berkumpul tapi tidak ada ikatan satu sama lain-barangkali seperti apa yang dikatakan Ferdinand Tonies sebagai gesselschaft. ${ }^{30}$ Kesadaran kolektif yang digagas Nursi didasarkan pada ikatan kesadaran ilahi. Maksudnya adalah bahwa kolektivitas manusia, bangsa, atau umat harus didasarkan pada kesadaran bahwa "kita"—orang-orang yang berada dalam kolektivitas tersebut meyakini eksisitensi Tuhan dengan segala atribut dan aturan-aturan yang diberikan-Nya. Oleh karena itu, konsep brotherhood merupakan manifestasi dari kesadaran kolektivitas ini.

\footnotetext{
${ }^{28}$ Baudrillard, In the Shadow, 28-29.

${ }^{29}$ Nursi, The Words, 746.

30 Ferdinand Tönnies berteori bahwa masyarakat terdiri dari dua model pelembagaan, yakni gemeinshaft (paguyuban) dan gesellschaft (patembayan). Diskusi panjang lebar mengenai dua teori ini dibahas secara terperinci dalam seri karya Ferdinand Tönnies, Community and Civil Society, ed. Jose Harris, terj. Jose Harris dan Margaret Hollis (Cambridge: Cambridge University Press, 2001). Lihat selengkapnya juga pembahasan panjang mengenai hal ini dalam Carsten Schlüter (Hrsg.), Hundert Jahre "Gemeinschaft und Gesellschaft": Ferdinand Tönnies in der internationalen Diskussion/Lars Clausen (Opladen: Leske u. Budrich, 1991).
} 
Konsep besar yang diusung Nursi tentang kolektivitas ini adalah apa yang dikenal dengan șabs- $\iota$ manevi (collective personality). Kesadaran ini dibangun berdasarkan pemahaman akan eksistensi Allah dengan mengakui posisi Rasulullah sebagai prior experiences dari konsep ini. Said Nursi menyatakan sebagai berikut:

... the present time is the time of the group, or social collectivity, not of the individual. However great a genius an individual is, even a hundredfold genius, if he is not the representative of a group and if he doesn't represent the collective personality of a group, he will be defeated in the face of the collective personality of an opposing group. $^{31}$

Dengan kesadaran kolektif ini, collective personality berada vis a vis dengan kesadaran sekularistik dan ateistik. Said Nursi menggambarkan kesadaran sekularistik dan ateistik ini dihasilkan oleh peradaban (civilization) yang kedua. Nursi membagi peradaban Eropa-sebagai sumber dari peradaban dunia sekarang ini, menjadi dua, yakni Eropa yang melahirkan kedisiplinan, kemajuan, penghargaan; dan Eropa yang melahirkan peperangan, permusuhan, subordinasi, inbuman order, dan lain sebagainya. ${ }^{32}$ Kesadaran kedua inilah yang berada "di seberang" kesadaran collective personality. Apa yang dimaksudkan Nursi dengan kesadaran ini? Nursi mengembangkan analisis bahwa dengan "memposisikan" ateisme dan sekularisme sebagai common enemy bagi sebuah masyarakat, pada hakikatnya ada ikatan yang kuat yang menyatukan personality tersebut.

Untuk konteks kehidupan kontemporer sekarang ini, collective personality ini termanifestasi dalam kesadaran dalam "menghadapi" empire sebagaimana diuraikan di atas. Manifestasi empire era kini adalah kemajuan teknologi yang akibatnya memisahkan subjek satu dengan lainnya, etos kerja yang rendah karena telah dipenuhi oleh kemajuan teknologi, kehidupan instant tanpa ada upaya keras, kemalasan, konsumerisme, dan lain sebagainya. Oleh karena itu, dengan membangun kesadaran itu muncul sebuah identitas yang akan mempersatukan dan menjadi pengikat collective personality (sabs-ı manevi), yakni keadilan dan moralitas yang menjadi fondasi ajaran Allah dan Rasulullah, dan hal ini tergambar jelas dari uraian Nursi:

Our way is also to adopt the morality of Muhammad (Upon whom be blessings and peace) and revive his practices. Our guide is the

31 Said Nursi, The Letters 1928-1932, terj. Şukran Vahide (İstanbul: Sözler Neşriyat, A.Ş., 1997 [1994]), 514.

${ }^{32}$ Nursi, The Flashes Collection, 160. 
Illustrious Shari'a, our sword its decisive proofs, and our aim to uphold the Word of God. All believers are in meaning members of our society, while formal membership is by making determined effort to raise to life in one's own world the Prophet's practices. ${ }^{33}$

Statemen ini merupakan gambaran normatif, sedangkan gambaran praktis untuk era sekarang adalah penerimaan atas konsep dasar Islam yang menjunjung tinggi keadilan dan moralitas yang didasarkan pada aturan Allah dan Rasulullah. Dengan demikian, apa yang diyakini, dipahami, dan dilakukan merupakan cerminan dari kesadaran ini. Nursi menulis,

O man! Your heart, identity, and nature are a mirror. The intense love of immortality in your nature and heart should be not for the mirror, nor for your heart and nature, but for the manifestation of the Enduring One of Glory, whose manifestation is reflected in the mirror according to the mirror's capacity. However, due to stupidity that love of yours is directed to other places. Since it is thus, say: "O Enduring One! You are the Enduring One!" That is, "Since You exist and You are enduring, whatever transience and nonexistence want to do to us, let them do it, it is of no importance!" ${ }^{34}$

Dengan identitas, sebuah bangsa/umat akan "eksis" dengan entitas yang selalu "ada" dengan segala potensi dan kemampuan untuk maju. Dengan berdasarkan pada semangat ini, kemandirian akan terbangun dengan sendirinya. Untuk inilah, Nursi kemudian memberikan gambaran yang jelas bahwa kemandirian untuk maju akan dapat berjalan dengan dilandasi sebuah identitas yang kuat, begitu sebaliknya, tidak mungkin kemandirian bisa terbangun dengan baik tanpa ada jati diri dan identitas yang melandasinya. Identitas inipun dijiwai oleh rasionalitas bukan taqlid buta kepada tindakan yang tidak berdasarkan pada rasionalitas. Dengan kata lain, identitas yang diusung Islam-menurut Nursi, didasarkan pada bukti, rasionalitas, dan pengetahuan.

We Muslim, who are student of Qur'ān, follow proof. We approach the truths of belief through reason, thought, and our hearts. We do not abandon proof for blind imitation of the clergy like some followers of other religion. Thus, in the future when reason, science, and technology prevail, the Qur'ān will surely then rule, pronouncements. ${ }^{35}$

33 Said Nursi, The Damascus Sermon, terj. Hamid Alghar (İstanbul: Sözler Publication A.S., 1997), 76.

${ }^{34}$ Nursi, The Flashes Collection, 185.

35 Said Nursi, Sünuhat (Istanbul: Sözler Yayınevi, 1977), 18. 
Identitas seperti inilah fondasi dari semangat kemandirian. Kemudian, kemandirian pada gilirannya akan melahirkan progress (kemajuan) dan development (pembangunan). Mengacu pada pemikiran Said Nursi dari Treatise on Frugality (Risalah ke-19 dari Flashes Collection), Muhammad Aslam Parvis, direktur Islamic Foundation for Science and Environment, India, mengatakan bahwa kemandirian umat akan bisa terbangun melalui tiga prinsip utama yang didasarkan pada konsep identitas di atas; yakni self-interest vs self-sacrifice (kepentingan pribadi vs pengorbanan), extravagance vs frugality (pemborosan vs hemat), dan greed (tamak, rakus) vs contentment (kepuasan, kesyukuran). ${ }^{36}$

Kemandirian akan terbangun dengan baik dengan menekan tiga sifat negatif dan mengembangkan tiga sifat mulia. Ketiga sifat tersebut dikontraskan dengan tujuan untuk menunjukkan bahwa hanya dengan sifat yang positiflah sifat negatif akan hilang, dan pada gilirannya akan melahirkan sebuah sikap yang baik untuk memajukan kondisi bangsa/umat.

Globalisasi ekonomi telah melahirkan sebuah tatanan ekonomi transnasional yang memicu kesadaran individualistik dan meluruhkan tatanan luhur milik sendiri. Oleh karena itu, dengan "mengorbankan diri" tidak mengikuti dan larut dalam arus globalisasi, harus menghargai kemampuan sendiri, menggali potensi sendiri, dan bangga terhadap karya-karya sendiri. Tentunya dengan mengikis kepentingankepentingan pribadi dan mengutamakan kepentingan kolektif dan mengorbankan kepentingan pribadi. Dengan menguraikan contoh yang sangat panjang dari capaian negara Jepang, Nursi mengungkapkan sebagai berikut:

I acquiring civilization we have to follow the Japanese, for together with taking from Europe the virtues of civilization, they have preserved their national customs, which are the means by which every people is perpetuated. ${ }^{37}$

Kemudian prinsip kedua efek langsung dari globalisasi adalah konsumerisme yang terus "mendorong" kesadaran manusia untuk selalu mengejar produk-prosuk up to date meskipun tidak sesuai dengan kebutuhan. Muncul satu sikap "malu” ketika mengenakan atau memakai produk yang out of date meskipun sesuai dengan kebutuhan. Inilah sebuah sikap exclusive pleasure hasil dari globalisasi ekonomi.

36 M. Aslam Parvis, "The Need to Reinforce Humane Values in the Wake of of Globalization”, dalam Sözler Publication A.S., Globalization, Ethics, and Bediuzzaman Said Nursi's Risale-i Nur (İstanbul: Sözler Publication A.S., 2004), 107-110.

${ }^{37}$ Said Nursi, Divan-ı Harb-i Örfi (Istanbul: Sözler Yayınevi, 1978), 62. 
Berbagai fenomena globalisasi itu akan melahirkan satu sikap yang extravagance (boros) dan melemahkan etos untuk mandiri. Said Nursi menjelaskan:

Excess and wastefulness lead to lack of contentment. And lack of contentment destroys enthusiasm for work; it causes laziness, opens the door to complaining about life, and makes the dissatisfied person complain continuously. Also, it destroys sincerity, and opens the door to hypocrisy. And it destroys selfrespect, and points the way to begging. ${ }^{38}$

Menurut aturan dari Allah-menurut Nursi-hal ini jelas merupakan penyakit sosial yang akan melemahkan kemandirian. Oleh karena itu, Nursi menawarkan sebuah sikap hemat. Hemat merupakan sebuah sikap yang tidak saja cermat dalam pengelolaan keinginan dan kebutuhan, tetapi juga merupakan sikap mental untuk memperoleh yang lebih banyak dan lebih baik dengan usaha keras dan rasional sesuai dengan aturan Allah dan Rasulullah. Nursi menulis:

As for frugality and economy, these result in contentment.

According to the Hadith, The contented person is respected, and the greedy person despised, a consequence of contentment is self-esteem. Also, it encourages effort and work. It increases enthusiasm, and leads to work. ${ }^{39}$

Kemudian yang terakhir adalah ketamakan versus kesyukuran. Sikap ini merupakan prinsip bahwa kemandirian akan dapat diwujudkan dengan menyuburkan kesyukuran dengan menekan sikap ketamakan. Nursi menjelaskan dalam risalahnya bahwa kesyukuran merupakan sikap menerima apa diberikan oleh Allah dengan merasa cukup, tetapi selalu diiringi dengan membelanjakannya dalam koridorkoridor yang telah ditentukan oleh Allah dan Rasulullah. Dengan sikap ini maka akan lahir etos untuk selalu mencukupkan kebutuhannya dengan usaha yang keras dan bekerja yang lebih baik. Sikap ini berbeda dengan ketamakan, yang merupakan sikap selalu ingin memproleh yang lebih banyak tanpa mempertimbangkan aturan-aturan Allah. Sikap ini tidaklah mendorong pada kemandirian, justru akan menjerumuskan pada sikap "buta" terhadap anugerah Allah. Apapun yang diperoleh tidak pernah merasa cukup, dan selalu akan menuntut lebih banyak lagi tanpa usaha keras. Nursi menjelaskan sebagai berikut:

\footnotetext{
${ }^{38}$ Nursi, The Flashes Collection, 197.

${ }^{39}$ Ibid.
} 
Also, the contentment arising from frugality opens the door of thanks and closes the door of complaint. Throughout his life, the contented person is thankful. And in so far as he is independent of others through his contentment, he does not seek their regard. The door of sincerity is opened, the door of hypocrisy closed. ${ }^{40}$

Akhirnya, dengan menyandarkan pada prinsip-prinsip di atas kemadirian akan dapat diwujudkan. Artinya, kemandirian meniscayakan sikap-sikap pendahuluan yakni identitas yang kokoh, baru kemudian lahirlah sikap kemadirian sebagai medium untuk kemajuan dan kebangunan.

\section{Catatan Akhir}

Kemandirian dan identitas merupakan sebuah prasyarat utama bagi kemajuan sebuah bangsa. Hal ini disebabkan karena identitas akan memberikan orientasi yang tegas mengenai pemikiran dan sikap dalam berperilaku. Identitas juga memberikan karakter yang sangat khas bagi sebuah bangsa ketika berhadapan dengan berbagai bangsa yang juga memiliki karakter yang khas.

Dengan ketegasan identitas yang dibangun, maka sebuah masyarakat akan memperoleh kemandirian dalam menghadapi berbagai persoalan yang datang kepadanya. Kemandirian itu meliputi sikap mental maupun praktis sosialnya. Implikasi sosiologis adari cara pandang yang didasarkan pada kemandirian adalah orientasi yang jelas sebuah masyarakat dalam menapaki tahapan-tahapan menuju pada kesejahteraan dan kemakmuran.

Dasar analisis dari identitas menurut Said Nursi adalah bahwa kemakmuran dapat dicapai dengan mengedepankan sikap-sikap etis yakni self sacrifice (pengorbanan), frugality (hemat, efisien), dan contentment (kepuasan, kesyukuran). Sikap-sikap etis ini menjadi sebuah "pre-asumsi" bagi terciptanya kemakmuran. Dengan demikian, menurut analisis di atas, sikap-sikap etis itu akan memberikan landasan bagi sikap-sikap praktis dalam menciptakan kesejahteraan dan kemakmuran.

\section{Daftar Rujukan}

Baudrillard, Jean. In the Shadow of Silent Majorities or the End of Social and Other Essays, terj. Paul Fross, John Johnston, dan Paul Patton. New York: Semiotext[e]. 1983.

\footnotetext{
40 Ibid., 198.
} 
Berkes, Niyazi. The Development of Secularism in Turkey. Montreal: McGill University Press, 1964.

Castells, Manuel. The City and the Grassroots. London: Edward Arnold (Publisher) Ltd., 1983.

Dagi, Ihsan D. "Transformation of Islamic Political Identity in Turkey: Rethinking the West and Westernization", Turkish Studies, Vol. 6, No. 1, 2005.

Davis, Gerald F. et al. Social Movements and Organization Theory. Cambridge: Cambridge University Press, 2005.

Ellul, Jacques. The Technological Society. New York: Vintage Book, 1964. Firmanzah, "Morotai dan APEC 2013", dalam http://www.setkab. go.id/artikel-5725-.html, diakses 22 Desember 2012, pukul 22.50 WIB.

Giddens, Anthony. The Consequences of Modernity. Oxford: Polity Press, 1990.

Hardt, Michael dan Negri, Antonio. Empire. Cambridge: Harvard University Press, 2001.

Hobsbawn, Eric. Primitive Rebel: The Archaic Form of the Social Movement in the Nineteenth and Twentieth Centuries. New York: W.W. Norton and Company, Inc., 1965.

Karpat, Kemal. "Nurculuk", "Nursi", dalam C.E. Bosworth et.al (eds.), The Encyclopaedia of Islam, Vol. 3. Leiden: E.J Brill, 1995.

Kroker, Arthur dan Cook, David. The Postmodern Scene, Experimental Culture and Hyper-Aesthetics. N.Y.: Mcmillan, 1988.

Mardin, Şerif (ed.). Culture Transitions in The Middle East. Leiden: E.J Brill, 1994.

----. "Religion in Modern Turkey", International Social Science Journal, Vol. 29, No. 2, 1977.

----. Religion and Social Change in Modern Turkey: The Case of Bediüzzaman Said Nursi. California: SUNY Press, 1989.

----. Religion and Social Change in Modern Turkey: The Case of Bediuzzaman Said Nursi. Albany: State University of New York (SUNY) Press, 1989.

Martinelli, Alberto. Global Modernization: Rethinking the Project of Modernity. London: Sage Publication, 2005.

McClelland, David C. "The Impulse to Modernization", dalam Myron Weiner (ed.), Modernization: The Dynamics of Growth. Cambridge, Mass.: VOA Forum Lectures, 1966. 
-----. The Achieving Society. Princenton, N.J.: O. Van Nostrand Company, 1961.

McLuhan, Marshall. Understanding Media: The Extensions of Man. New York: McGraw-Hill Book Co., 1964.

Nursi, Said. Divan-ı Harb-i Örfi. Istanbul: Sözler Yayınevi, 1978.

----. Lem'alar. İstanbul: CD ROM Risale-i Nur 1.0, t.th.

----. Sünubat. Istanbul: Sözler Yayınevi, 1977.

----. The Damascus Sermon, terj. Hamid Alghar. İstanbul: Sözler Publication A.S., 1997.

----. The Flashes Collection, terj. Şukran Vahide. İstanbul: Sözler Neşriyat, A.S.., 2000 [1995].

----. The Letters 1928-1932, terj. Şukran Vahide. İstanbul: Sözler Neşriyat, A.Ş., 1997 [1994].

----. The Words, terj. dari 'Sözler' oleh Sukran Vahide. İstanbul: Sözler Neşriyat, Ticaret ve Sanayi, A.Ş., 1992.

Parvis, M. Aslam. "The Need to Reinforce Humane Values in the Wake of of Globalization", dalam Sözler Publication A.S., Globalization, Ethics, and Bediuzzaman Said Nursi's Risale-i Nur. İstanbul: Sözler Publication A.S., 2004.

Publications, Söler. Jihad of the Word and Positive Action: Bediurzaman Said Nursi's Interpretation of Jihad in the Modern Age. Istanbul: Söler Publications, t.th.

Sambur, Bilal. "The Great Transformation of Political Islam in Turkey: The Case of Justice and Development Party and Erdogan", European Journal of Economic and Political Studies (2), 2009. Schlüter, Carsten (Hrsg.). Hundert Jahre "Gemeinschaft und Gesellschafe": Ferdinand Tönnies in der internationalen Diskussion/Lars Clausen. Opladen: Leske u. Budrich, 1991.

Tönnies, Ferdinand. Community and Civil Society, ed. Jose Harris, terj. Jose Harris dan Margaret Hollis. Cambridge: Cambridge University Press, 2001.

Weiner, Myron (ed.). Modernization: The Dynamics of Growth. Cambridge Mass.: VOA Forum Lectures, 1966.

Yavuz, M. Hakan. "Towards an Islamic Liberalism? The Nurcu Movement of Fettullah Gulen”, Middle East Journal, Vol. 53, No.4, 1999. 